\section{Bone Proliferation in Ankylosing Tarsitis Might Involve Mechanical Stress, and Hormonal and Growth Factors}

To the Editor:

We thank The Journal for the opportunity to address some details in the editorial by Appel and Sieper ${ }^{1}$ about our recent paper "Bone Lineage Proteins in the Entheses of the Midfoot in Patients with Spondyloarthritis"2.

As Appel and Sieper stated ${ }^{1}$, we reported the lack of inflammatory lesions in our set of tissue samples ${ }^{2}$. Yet in contrast to their interpretation, our findings did not result from the study of patients in the advanced stage of what we have called "ankylosing tarsitis", but for reasons that were already mentioned in the paper.

Figure 1 does not represent the population included in the study; it illustrates only the most advanced stage of ankylosing tarsitis ${ }^{2}$. In fact, there were only 3 patients $(16.6 \%)$ classified as Grade 4 according to the SpondyloArthropathies Tarsal Radiographic Index (SpA-TRI) ${ }^{3}$.

The SpA-TRI is an instrument designed for the evaluation of the radiographic changes that occur in the tarsus and adjacent areas of the foot in patients with SpA. The involvement of the foot, particularly the tarsus, is a prominent feature in Mexican children and adolescents with $\mathrm{SpA}$ - and certainly in other ethnicities - that resembles the structural changes of the spine in patients with ankylosing spondylitis (AS). The characteristics of SpA-TRI grading and the percentage of patients included in each of them in our study are shown in Table 1. We regret that this information was not included in the original publication.

We decided to include the figure with a radiograph of an ankylosing tarsitis graded 4 to better show the reader a not very well-known clinical entity. It is also intended to show the aggressiveness of the process, and moreover the realistic rather than metaphoric name - ankylosing tarsitis - that we gave to this condition around the mid- $80 \mathrm{~s}^{4,5}$, and to show the parallels with AS in regard to the severity of bone proliferation that can be established. Indeed, Figure 1 and the related text appear in the second paragraph of "Introduction" to deal with the concept and definition of ankylosing tarsitis.

We indeed agree with Appel and Sieper's ${ }^{1}$ idea that acute inflammatory lesions are not necessarily expected in this advanced stage, which probably refers to Grade 4 ankylosing tarsitis. Yet again they failed to recognize that not all our patients had longterm advanced disease and that the lack of inflammation we found in our tissue samples was also described in early inflammatory cases. Interestingly, they referred to Gong, et al's ${ }^{6}$ study of patients with short-term AS ( 3 to 4 yrs). Certainly, we included patients with active disease, defined by pressure tenderness and sometimes swelling in various areas of the foot, raised serum C-reactive protein, and in some cases inflammation on magnetic resonance of the feet. We also showed active

Table 1. Grading, description, and patients in each category of SpA-TRI.

\begin{tabular}{llc}
\hline Grade & Description & $\mathrm{n}(\%)$ \\
\hline 0 & $\begin{array}{l}\text { Normal } \\
\text { Osteopenia or suspicious findings, joint space } \\
\text { narrowing, bony erosion(s), periosteal } \\
\text { whiskering, enthesophyte(s). }\end{array}$ & 0 \\
2 & $\begin{array}{l}\text { Definite joint space narrowing, bony erosion(s), } \\
\text { periosteal whiskering (no joint space involved), } \\
\text { or enthesophyte(s) in the plantar fascia or } \\
\text { Achilleal tendon attachments. }\end{array}$ & 0 \\
3 & $\begin{array}{l}\text { Paraarticular enthesophyte(s), incomplete } \\
\text { bridging. } \\
\text { Bony ankylosis, joint space fusion, or complete } \\
\text { bridging. }\end{array}$ & $6(50.0)$ \\
& $6(33.3)$
\end{tabular}

SpA-TRI: SpondyloArthropathies Tarsal Radiographic Index. Modified from Pacheco-Tena, et al. Ann Rheum Dis 2002;61:330-4; with permission. joints and entheses counts, as well as the Bath Ankylosing Spondylitis Disease Activity Index data to confirm the inflammatory stage of the disease. Regarding disease duration, Table 1 of the paper shows $2.39 \pm 0.79$ years in the group already having bone proliferation.

In agreement with Appel and Sieper ${ }^{1}$, the lack of inflammatory infiltrates in advanced stage of the disease is more than expected. In contrast, the absence of inflammatory cells in areas close to proliferative changes should bring into question the role of inflammation in bone ankylosis and syndesmophyte formation. Cortical whiskering seems to be an early finding in peripheral SpA (including reactive and psoriatic arthritis), associated with entheseal cells and fibroblasts shifted toward bone lineage, as shown by the abnormal expression of bone-specific proteins. Despite some limitations, our findings suggest that bone proliferation in ankylosing tarsitis might require not the effect of activated immune response cells, but other factors, including mechanical stress, hormonal differentiation and maturation, and growth factors.

CÉSAR PACHECO-TENA, MD; SUSANA A. GONZÁLEZ-CHÁVEZ, MSc; CELIA QUIÑONEZ-FLORES, MSc, Facultad de Medicina, Universidad Autónoma de Chihuahua; RUBÉN BURGOS-VARGAS, MD, Servicio de Reumatología, Hospital General de México, Facultad de Medicina, Universidad Nacional Autónoma de México. Address correspondence to Dr. R. Burgos-Vargas, Rheumatology Department, Hospital General de México, Dr. Balmis 148, México DF 06720, México. E-mail: r.burgos.vargas@gmail.com

\section{REFERENCES}

1. Appel H, Sieper J. Analysis of bone samples from patients with spondyloarthritides-identifying causes of new bone formation in axial spondyloarthritis. J Rheumatol 2015;42:561-3.

2. Pacheco-Tena C, Pérez-Tamayo R, Pineda C, González-Chávez SA, Quiñonez-Flores C, Vitelly A, et al. Bone lineage proteins in the entheses of the midfoot in patients with spondyloarthritis. J Rheumatol 2015;42:630-7.

3. Pacheco-Tena C, Londoño JD, Cazarín-Barrientos J, Martínez A, Vázquez-Mellado J, Moctezuma JF, et al. Development of a radiographic index to assess the tarsal involvement in patients with spondyloarthropathies. Ann Rheum Dis 2002;61:330-4.

4. Burgos-Vargas R, Madariaga-Ceceña MA, Katona-Salgo G. [Juvenile ankylosing spondylitis: clinical characteristics in 41 patients]. [Article in Spanish] Bol Med Hosp Infant Mex 1985;42:523-30.

5. Burgos-Vargas R, Granados Arriola J. Ankylosing spondylitis and related diseases in the Mexican mestizo. In: Khan MA, ed. Seronegative spondyloarthropathies. Philadelphia: Hanley \& Belfus; 1990:665-78.

6. Gong Y, Zheng N, Chen SB, Xiao ZY, Wu MY, Liu Y, et al. Ten years' experience with needle biopsy in the early diagnosis of sacroiliitis. Arthritis Rheum 2012;64:1399-406.

J Rheumatol 2015;42:11; doi:10.3899/jrheum.150475

$$
\text { Personal non-commercial use only. The Journal of Rheumatology Copyright (C) 2015. All rights reserved. }
$$

